https://journal-computing.org/index.php/journal-cisa/index

\title{
Perancangan dan Implementasi Sistem Informasi Forum Jual Beli Properti Berbasis Web
}

\author{
Koo, Yansen Manuel Harun1, Agustinus Fritz Wijaya² \\ Program Studi Sistem Informasi Universita Kristen Satya Wacana \\ Jalan Dr. O. Notohamidjojo No. 1 - 10, Salatiga, Indonesia \\ Email:1682017002@student.uksw.edu, 2agustinus.wijaya@uksw.edu
}

\begin{abstract}
Abstrak
Perkembangan teknologi pada sistem informasi berkembang sangat pesat, salah satunya yaitu internet. Saat ini internet telah digunakan sebagai media oleh pebisnis properti. Properti tidak hanya dapat digunakan sebagai tempat tinggal, melainkan dapat digunakan sebagai investasi pula. Pada penelitian ini dibuat sebuah rancang bangun yang berguna sebagai sistem informasi untuk menyediakan forum tempat mencari informasi ataupun berdiskusi tentang jual beli properti berbasis web. Dengan basis web dapat dengan mudah dicari di Internet. Dalam forum ini seseorang bisa dengan mudah mencari properti yang dibutuhkan, dan bisa menjual atau menawarkan properti miliknya. Cutomer dapat berdiskusi, berbagi informasi tentang properti. Dengan menggunakan metode Use case untuk mengidentifikasikan entitas, data dan proses-proses yang terjadi dalam sistem. Penelitian ini berupa prototipe sistem informasi forum jual beli Properti berbasis web yang dapat diakses oleh pungunjung ataupun pemilik properti untuk menjual atau memasarkan dengan mudah. Rancang bangun web pada penelitian ini dinamakan PropertiKu. Sistem ini dibangun bertujuan untuk digunakan sebagai wadah bagi masyarakat yang ingin menjual properti dan mencari properti dengan mudah. PropertiKu dirancang agar memberikan efektifitas bagi pengunjung dalam mendapatkan informasi properti yang diinginkan.
\end{abstract}

Keywords: Forum, Properti, Sistem Informasi, Use Case, Web

\section{PENDAHULUAN}

Perekonomian di Indonesia berkembang begitu pesat, hal itu ditandai dengan banyaknya bidang-bidang usaha yang muncul yaitu sebagian besar berasal dari bidang perdagangan [1]. Sebagai dampak dari adanya bidangbidang usaha yang baru, tentunya setiap perusahaan melakukan bermacam-macam usaha untuk membuar perusahaan tersebut agar tidak kalah bersaing dengan perusahaan lain, salah satunya perusahaan di 
Vol. 3, No. 1, January 2022 e-ISSN: 2775-2496

https://journal-computing.org/index.php/journal-cisa/index

bidang properti. Bisnis properti adalah salah satu jenis bisnis yang semakin berkembang di Indonesia. Kebutuhan lahan tempat tinggal yang terus meningkat membuat bisnis ini semakin diminati. Selain itu, orang yang membeli properti tidak hanya untuk tempat tinggal, namun banyak yang membeli properti untuk berinvestasi, sehingga peluang bisnis properti ini sangat menjanjikan [2].

Pada zaman dahulu, kegiatan transaksi bisnis dilakukan secara langsung dan penyimpanan data-data penjualan secara manual, dimulai dari pencatatan pembeli, penyimpanan data-data penjualan, dan laporan keuangan dilakukan secara manual. Seiring dengan perkembangan zaman, teknologi pun semakin berkembang salah satunya internet. Internet saat ini banyak digunakan sebagai portal untuk penjualan serta penyewaan khusus properti salah satunya dengan menggunakan website diantaranya yaitu www.jualbelipropertico.id, www.rumah123.com, dan lain sebagainya. Perkembangan internet sudah menjadi salah satu fasilitas paling baik yang dapat digunakan untuk melakukan bisnis properti. Untuk meningkatkan perpaduan internet dan bisnis yang kuat maka diperlukan penyimpanan dan pengelolaan data yang baik dan optimal. Salah satu cara untuk mendapatkan hasil yang optimal yaitu dengan mengelola data yang cepat dan akurat, maka dapat digunakan sebuah sistem komputerisasi untuk mendapatkan hasil yang optimal tersebut, yaitu dengan menggunakan Software Development Life Cycle (SDLC) dengan metode Waterfall dalam perencanaan sistem informasi [3] [4].

Beberapa ahli menjelaskaan mengenai sistem serta sistem informasi. Salah satunya yaitu menurut Yasin dalam jurnal Abdurrahman [1], sistem merupakan suatu kumpulan variabel yang terorganisisr, saling berinteraksi dan bergantung satu sama lain. Sementara SLDC merupakan sebuah proses pemahaman dalam mengubah atau mengembangkan suatu sistem perangkat dengan menggunakan metodologi dan model-model yang digunakan dalam mengembangkan perangkat lunak [5]. Di dalam sistem ini, perangkat pendukung yang digunakan yaitu Unified Modeling Language (UML). Dimaa UML merupakan sebuah bahasa pemodelan yang digunakan untuk sebuah perangkat lunak atau sistem yang berorientasi pada objek dari sebuah permasalahan yang kompleks ke permasalahan yang lebih sederhana[6]. Untuk penerapan ke dalam database dibutuhkan Entiti Relationship Diagram (ERD) yang merupakan sebuah rancangan dalam sistem yang berkaitan langsung dan juga memiliki fungsi di dalam proses pada sistem tersebut [7]. 
Vol. 3, No. 1, January 2022 e-ISSN: 2775-2496

https://journal-computing.org/index.php/journal-cisa/index

Salah satu penelitian terkait dengan metode Waterfall yaitu yang dilakukan oleh Wyzer mengenai implementasi metode Waterfall dalam rancang bangun aplikasi untuk penjualan alat musik yang menerapkan sistem website yang user friendly. Sistem dengan menggunakan metode ini dapat memudahkan dalam penyusunan tiap tahapan dalam pengembangan sistem [8]. Oleh karena itu, apabila menggunakan metode Waterfall maka dapat memudahkan dalam menyusun tahap-tahap dalam pengembangan sistem. Dengan sistem yang efiien akan meningkatkan ketelitian dan kecepatan pun lebih terjamin, sehingga dapat mempermudah dalam mencari data. Selain itu, penelitian dengan metode Waterfall dapat membantu dalam meminimalkan kesalahan yang mungkin terjadi [9].

Oleh karena itu, pada penelitian ini akan dilakukan pengembangan rancang bangun sistem informasi forum jual beli properti yang berbasis website dengan menggunakan Software Development Life Cycle (SDLC) dengan metode Waterfall yang bertujuan untuk memudahkan seseorang dalam melakukan transaksi jual-bei ataupun mencari properti yang dibutuhkan dengan mudah. Selain itu, dapat digunakan sebagai wadah diskusi antar penjual dan pembeli mengenai properti dan berbagi informasi dengan mudah, yang meliputi identifikasi dari sistem seperti entitas, data, dan proses yang terjadi hingga prototipe dari sistem yang dirancang. Penelitian ini diharapkan dapat membantu dalam mengembangkan bisnis properti berbasis website.

\section{METODOLOGI}

Pada penelitian ini dilakukan dengan menggunakan metodelogi pengumpulan data dan perancangan sistem. Untuk metode pengumpulan data terdiri dari tiga bagian, yaitu:

\subsection{Studi Pustaka}

Dilakukan dengan mempelajari teknologi yang akan digunakan delam perancangan sistem informasi dan implementasinya dengan cara membaca artikel-artikel yang ada di internet dan sumber-sumber lainnya.

\subsection{Wawancara}

Penulis melakukan pendekatan secara langsung dengan subjek ataupun objek yang akan diteliti dengan cara mengajukan pertanyaan kepada narasumber yang ngenguasai bidangnya.

\subsection{Observasi}

Pada tahapan ini dilakukan dengan secara langsung melakukan pengamatan di objek penelitian. 
Vol. 3, No. 1, January 2022 e-ISSN: 2775-2496

https://journal-computing.org/index.php/journal-cisa/index

\subsection{Perancangan Sistem Model}

Untuk perancangan sistem penulis mengunakan metode System Development Life Cycle (SDLC) Model Waterfall. Dalam metode waterfall terdapat ada lima tahap yaitu ;

\subsubsection{Perancangan sistem}

Pada tahap digunakan untuk melihat dan menentukan apa yang dibutuhkan sistem yang akan digunakan dalam penerapan rancangan pembuatan sistem.

\subsubsection{Analisis}

Pada tahap ini bertujuan untuk mencari dan memahami kebutuhan user ataupun organisasi untuk mengetahui ruang lingkup informasi, fungsi yang dibutuhkan, dan kinerja yang diharapkan dalam perancangan sistem infromasi tersebut.

\subsubsection{Design}

Tahap design dilakukan untuk memfokuskan pada komponen-komponen dalam sistem seperti kerangka sistem, struktur data, detail prosedur, yang sesuai dengan tahap analisis.

\subsubsection{Implementasi (coding dan testing)}

Tahap ini dilakukan dengan penulisan Bahasa program agar sistem informasi dapat berjalan oleh komputer dan melakukan pengujian apakah berjalan seusai analisis dan design yang diharapkan.

\subsubsection{Pemeliharaan}

Tahapan pemeliharaan ini dilakukan saat sistem yang telah dirancang dan dibuat sudah beroperasi, untuk menjaga agar sistem tetap berjalan dengan baik adanya rutinitas melakukan pengecekan pada sistem dan memonitoring sistem agar tidak ada kesalahan pada sistem yang sedang berjalan.

Untuk tahapan perancangan SLDC Model Waterfall dapat dilihat pada Gambar 1.

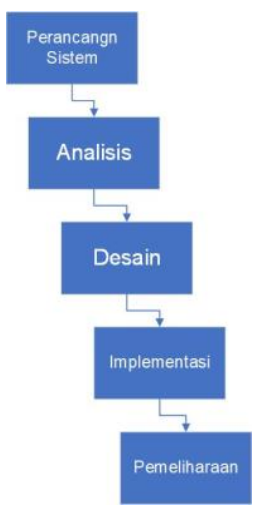

Gambar 1. Tahap Perancangan SDLC Model Waterfall 
Vol. 3, No. 1, January 2022 e-ISSN: 2775-2496

https://journal-computing.org/index.php/journal-cisa/index

2.5. Dalam perancangan sistem informasi berbasis website pada penelitian ini menggunakan diagram perancangan yaitu sebagai berikut

\subsubsection{Use Case Diagram}

Pada proses Use Case Diagram dilakukan untuk menggambarkan urutan kegiatan atau interaksi antara aktor dengan sistem, aktor sendiri bisa disebut user ataupun admin.

\subsubsection{Activity Diagram}

Pada tahapan ini dilakukan untuk menggambarkan dan mendiskripsikan kegiatan yang terjadi dalam sistem.

2.6. Dalam perancangan web pada penelitian ini dilakukan dengan menggunakan XAMPP dan Wordpress.

\subsubsection{XAMPP}

Menurut Priyanto dan Jauhari (2015:1), "Xampp merupakan paket PHP berbasis open source yang dikembangkan oleh komunitas Open Source, yang mendukung banyak sistem operasi, merupakan kompilasi dari beberapa program. Fungsinya adalah sebagai server yang berdiri sendiri (localhost), yang terdiri atas program Aphace HTTP Server, MySQL database, dan penerjemah bahasa yang ditulis dengan bahasa pemrogaman PHP dan pearl. Nama XAMPP merupakan singkatan dari X (empat sistem operasi apapun), Apacche, MySQL, PHP dan Pearl. Program ini tersedia dalam GNU (General Public License) dan bebas, merupakan web server yang mudah digunakan yang dapat melayani tampilan halaman web yang dinamis."

\subsubsection{Wordpress}

Sebuah aplikasi open source yang sangat popular digunakan sebagai mesin blog. Wordpress dibangun dengan Bahasa pemrogramman PHP dan basis data (database) MySQL. Selain sebagai blog, Wordpress juga mulai digunakan sebagai CMS (Content Management System) karena kemampuannya untuk memodifikasi dan disesuaikan kebutuhan penggunanya.

\section{HASIL DAN PEMBAHASAN}

Peneliti melakukan observasi dan wawancara secara langsung menemui beberapa narasumber yang menjual properti, seperti pemilik apartmen, tanah, rumah, rumah toko, dan lain-lain. Peneliti menawarkan sebuah forum jual beli properti yang dimana narasumber dapat menawarkan 
Vol. 3, No. 1, January 2022 e-ISSN: 2775-2496

https://journal-computing.org/index.php/journal-cisa/index

properti nya secara langsung dengan mudah dan gratis. Forum jual beli properti berbasis web yang ditawarkan merupakan wadah bagi pemilik properti dapat memasarkan dengan mudah dan pengunjung yang membutuhkan properti dapat memilih dan berdiskusi dengan pemilik atau penjual properti dengan mudah.

\section{Perancangan Design Sistem Usulan}

\section{Use Case Diagram}

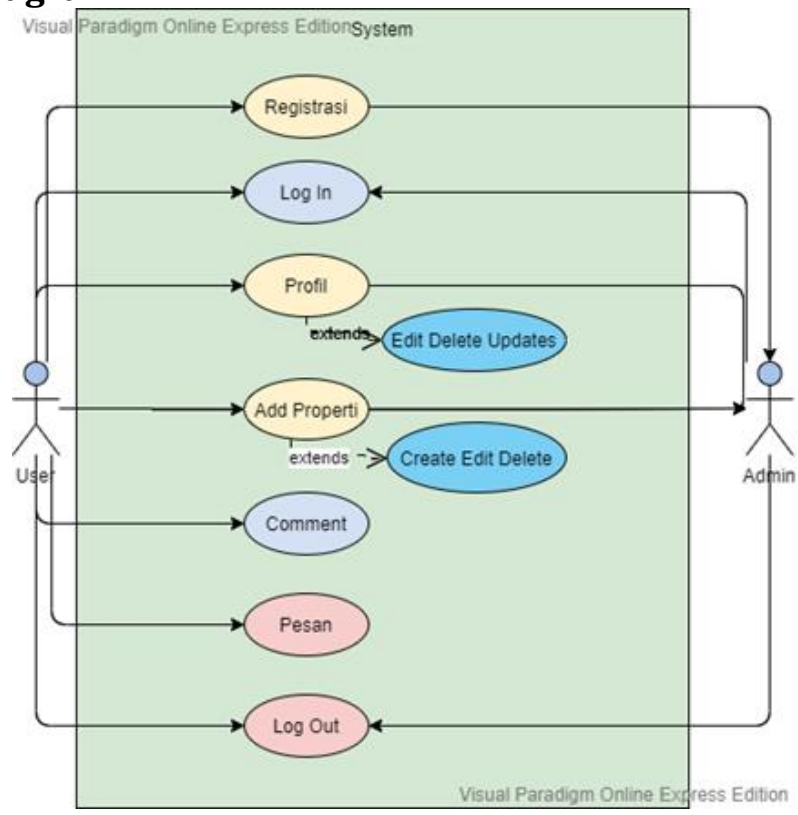

Gambar 2. Use Case Diagram Usulan

Use case diagram adalah satu dari berbagai jenis diagram UML (Unified Modelling Language) yang menggambarkan hubungan interaksi antara sistem dan aktor. Use Case dapat mendeskripsikan tipe interaksi antara si pengguna sistem dengan sistemnya. Menurut istilah, use case adalah sebuah kegiatan atau interaksi yang saling berkaitan antara aktor dan sistem. Atau secara umum, dapat diartikan sebagai sebuah teknik untuk yang dimanfaatkan untuk pengembangan perangkat lunak (software), guna mengetahui kebutuhan fungsional dari sistem tersebut.

Definisi dari use case diagram sendiri adalah proses penggambaran yang dilakukan untuk menunjukkan hubungan antara pengguna dengan sistem yang dirancang. Hasil representasi dari skema tersebut dibuat secara 
Vol. 3, No. 1, January 2022 e-ISSN: 2775-2496

https://journal-computing.org/index.php/journal-cisa/index

sederhana dan bertujuan untuk memudahkan user dalam membaca informasi yang diberikan.

\section{Tahap-Tahap Use Case Diagram Usulan}

1) Website Usulan Penulis bernama Properti Shop.

2) Terdapat 2 Aktor dalam sistem yang berjalan.

3) Aktor User di Bedakan menjadi 2 yaitu Penjual dan Pengunjung

4) Aktor Penjual Harus meregistrasi atau mendaftar agar dapat menjual Properti.

5) Registrasi mencangkup data diri agar meminimalkan terjadinya penipuan property.

6) Data-data member Penjual akan tersimpan oleh Admin di dalam database.

7) Aktor penjual dapat akses Edit Delete Create untuk Properti yang di Posting dalam Forum Website PropertiKu.

8) Aktor Penjual dan Pengunjung dapat melakukan diskusi di kolom komentar Propeti maupun Pesan langsung.

\section{Activity Diagram}

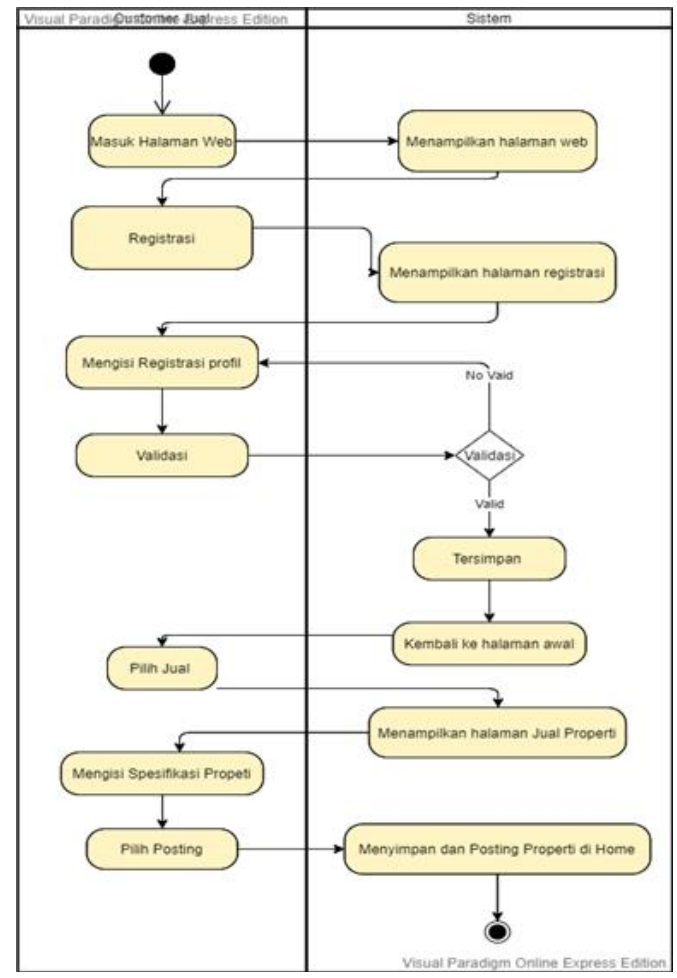


Vol. 3, No. 1, January 2022 e-ISSN: 2775-2496

https://journal-computing.org/index.php/journal-cisa/index

Gambar 3. Activity diagram Penjual

Activity diagram, dalam bahasa Indonesia diagram aktivitas, yaitu diagram yang dapat memodelkan proses-proses yang terjadi pada sebuah sistem. Runtutan proses dari suatu sistem digambarkan secara vertikal. Activity diagram merupakan pengembangan dari Use Case yang memiliki alur aktivitas. Alur atau aktivitas berupa bisa berupa runtutan menu-menu atau proses bisnis yang terdapat di dalam sistem tersebut.

\section{Tahap-Tahap Activity diagram Penjual :}

1) Aktor Penjual mengunjungi website PropertiKu/

2) Aktor Penjual ingin menjual atau mempublikasikan Properti miliknya.

3) Aktor Penjual Melakukan Registrasi .

4) Aktor Penjual Mengisi semua berkas yang terdapat di laman daftar .

5) Verifikasi dilakukan menggunakan nomor pribadi .

6) Aktor Penjual dapat memposting Properti .

7) Aktor Penjual mengisi spesifikasi dari Properti miliknya seperti ukuran, letak/ alamat, harga, gambar , dan sebagainya.

8) Aktor Penjual memposting Properti di website PropertiKu.

\section{Rancangan Tampilan Website}

\section{Tampilan Beranda Web Usulan}
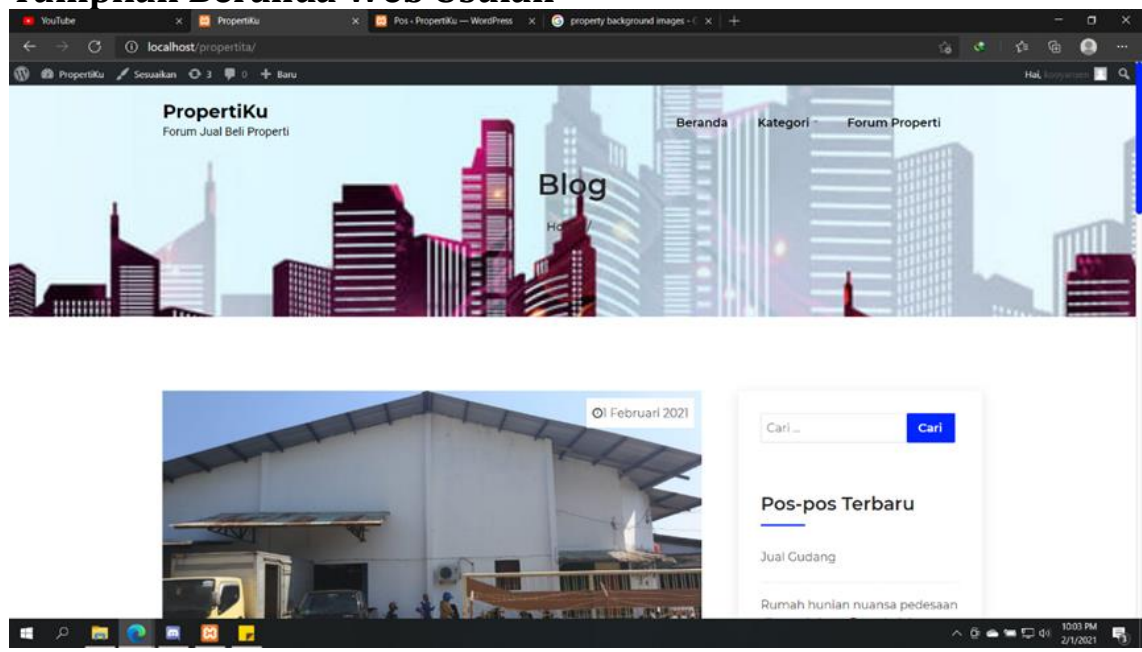

Gambar 5. Tampilan Web Usulan 
Vol. 3, No. 1, January 2022 e-ISSN: 2775-2496

https://journal-computing.org/index.php/journal-cisa/index

Untuk tampilan website usulan dari forum jual beli properti yang masih berada pada localhost, dan menggunakan wordpress dalam perancangan website usulan. Pada tamapilan beranda website PropertiKu ini terdapat menu untuk beranda, kategori untuk memilah jenis-jenis postingan dari properti. Pada beranda PropetiKu sendiri langsung menampilkan postingan dari anggota yang sudah terdaftar untuk bisa memposting propertinya, desain dari website PropertiKu ini menampilkan postingan terbaru dari anggota , apabila untuk memudahkan mencari property yang diinginkan bisa menggunakan kategori untuk memilah jenis-jenis property yang diinginkan, sehingga tampilan beranda pada website PropertiKu bisa menampilkan sesuai kategori dari yang pengunjung inginkan.

\section{Tampilan Daftar Pengguna}

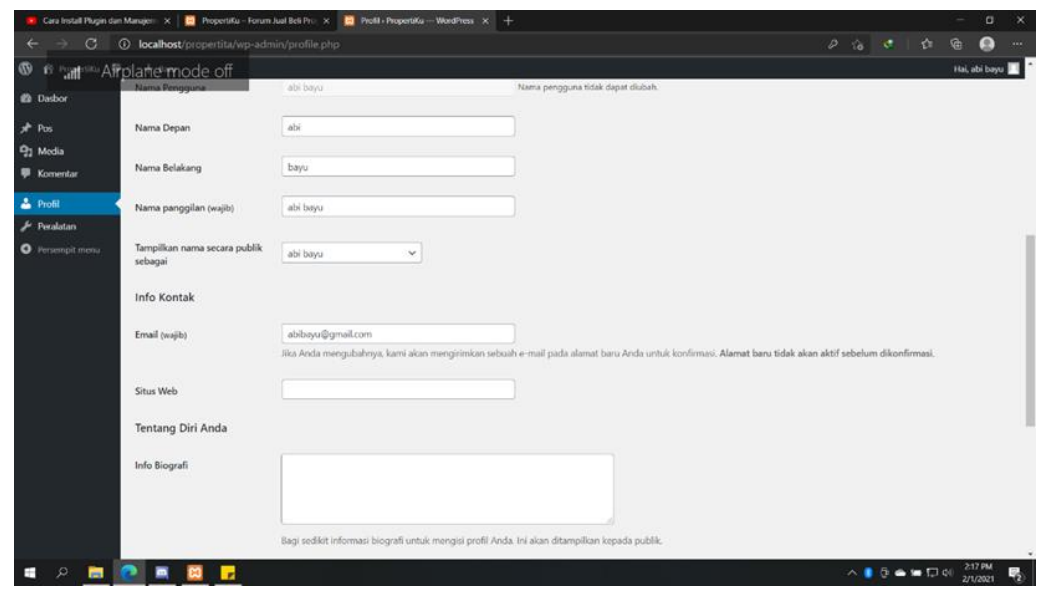

Gambar 6. Tampilan Daftar Pengguna atau Penjual

Untuk pengunjung yang ingin menjualkan properti miliknya harus mendaftar untuk bisa memposting properti miliknya. Untuk tampilan daftar anggota bisa dilihat harus mengisi kolom nama, lalu anggota harus memiliki info kontak yang cukup lengkap agar menghindari penipuan seperti alamat email, nomor telpon yang dapat dihubungi. Semua informasi ini masuk dalam database yang sudah dibuat oleh admin sehingga informasi anggota bisa terjaga dan tidak disalahgunakan. Infromasi anggota juga penting dan harus terferivikasi agar mengghindari penipuan. 
Vol. 3, No. 1, January 2022 e-ISSN: 2775-2496

https://journal-computing.org/index.php/journal-cisa/index

\section{Tampilan Penjual Posting}

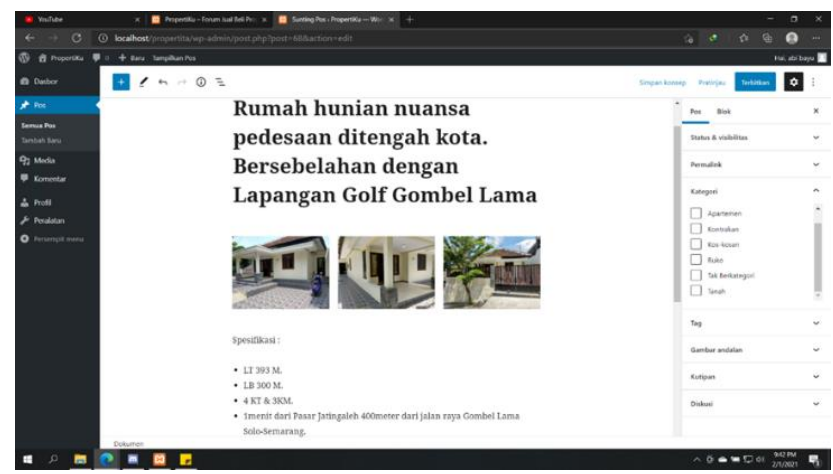

Gambar 7. Tampilan Penjual Posting Web

Tampilan saat penjual akan memposting property di website PropertiKu agar dapat muncul dalam beranda website PropertiKu. Pada Tampilan postingan maka terdapat beberapa tools atau fungsi kegunaan yang bisa digunakan oleh anggota untuk menampilkan atau memposting propreti miliknya. Pada bagian kanan dapat dilihat terdapat beberapa kolom yang tersedia seperti pilihan untuk katagori, untuk mengkhususkan jenis postingan anggota ini tergolong dalam katagori apa, untuk tersedia pada sortiran katagori. Pada kolom postingan ini bisa sampai menampilkan banyak gambar agar postingan property bisa sangat detail dan menarik bagi para penggunjung website PropertiKu. Lalu jika akan memposting maka akan terkirim kepada admin terlebih dahulu untuk diverifikasi oleh admin, dan apabila postingan dirasa cukup maka bisa posting di beranda website PropertiKu.

\section{Tampilan Pengunjung Komentar di Postingan}


Vol. 3, No. 1, January 2022 e-ISSN: 2775-2496

https://journal-computing.org/index.php/journal-cisa/index

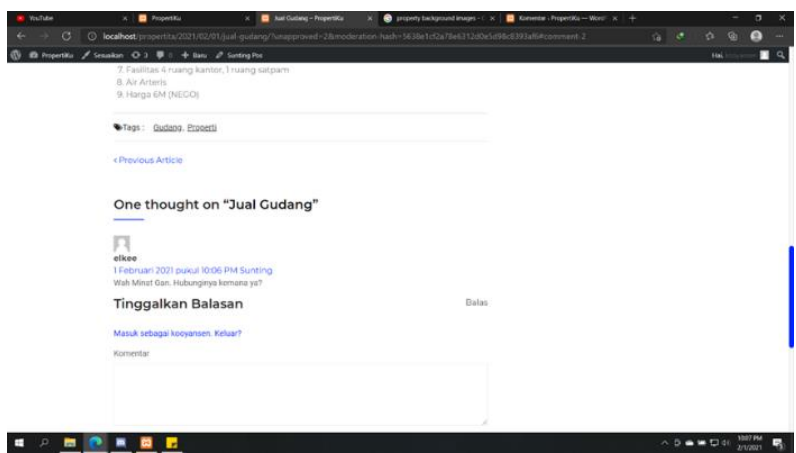

Gambar 8. Pengunjung Komentar di Sebuah Postingan

Tampilan saat diskusi atau pengunjung meninggalkan komentar dalam postingan penjual di website PropertiKu. Setelah sistem informasi website PropertiKu telah selesai dirancang dan dibuat, kemudian dilakukan penawaran dan promosi terhadap pengguna dan peminat bisnis properti dan didapatkan hasil bahwa sistem informasi yang dibangun telah mampu membangun minat dan dapat menjadi wadah dari pelaku bisnis properti di masyarakat.

\section{KESIMPULAN}

Berdasarkan hasil penelitian yang sudah dilakukan oleh peneliti maka dapat dibuat sebuah Sistem Informasi dari sebuah forum jual beli properti berbasis website yang bernama PropertiKu. Sistem ini dibangun bertujuan untuk digunakan sebagai wadah bagi masyarakat yang ingin menjual properti dan mencari properti dengan mudah. Sistem Informasi Forum ini dirancang agar memberikan efektifitas bagi pengunjung dalam mendapatkan informasi properti yang diinginkan. Website PropertiKu masih banyak memiliki kekurangan sehingga masih membutuhkan proses pemeliharaan agar bisa menjadi lebih baik untuk pengunjung Forum Jual Beli Properti.

\section{DAFTAR PUSTAKA}

[1] A. Abdurrahman and S. Masripah, "Metode Waterfall Untuk Sistem Informasi Penjualan," Inf. Syst. Educ. Prof., vol. 2, no. 1, pp. 95 - 104, 2017.

[2] R. P. Putra, A. Riyadi, and S. Wardani, "Rancang Bangun Sistem Informasi Persewaan Dan Penjualan Properti Di Diy Berbasis Web," Semin. Nas. Din. Inform. 2017 Univ. PGRI Yogyakarta., pp. 302-311, 2017,

[Online].

Available: 
http://repository.upy.ac.id/id/eprint/1490.

[3] M. Tabrani and E. Pudjiarti, "PENERAPAN METODE WATERFALL PADA SISTEM INFORMASI INVENTORI PT. PANGAN SEHAT SEJAHTERA," J. Infokar, vol. 1, no. 2, pp. 30-40, 2017.

[4] H. Nur, "Penggunaan Metode Waterfall Dalam Rancang Bangun Sistem Informasi Penjualan," Gener. J., vol. 3, no. 1, p. 1, 2019, doi: 10.29407/gj.v3i1.12642.

[5] M. Bolung and H. R. K. Tampangela, "Analisa Penggunaan Metodologi Pengembangan Perangkat Lunak," J. ELTIKOM, vol. 1, no. 1, pp. 1-10, 2017, doi: 10.31961/eltikom.v1i1.1.

[6] E. F. Wati and A. A. Kusumo, "Penerapan metode unified modeling language ( UML ) berbasis desktop pada sistem pengolahan kas kecil studi kasus pada PT indo mada yasa tangerang," J. Inform., vol. 5, no. 1, pp. 24-36, 2016, [Online]. Available: https://journal.unsika.ac.id/index.php/syntax/article/view/699.

[7] P. I. Permana, "Sistem Informasi Perpustakaan Sekolah Berbasis Web dengan Framework Codeigniter dan PostgreSQL," Skripsi, no. 2, pp. 8-35, 2013.

[8] M. Wyzer, Y. Durachman, and V. Arifin, "Aplikasi Penjualan Produk Alat Musik Berbasis Web ( Studi Kasus PT . Duta Karya Musikindo Jakarta )," Sist. Inf., vol. 4, no. 1, pp. 1-7, 2011.

[9] H. Larasati and S. Masripah, "Analisa Dan Perancangan Sistem Informasi Pembelian Grc Dengan Metode Waterfall," J. Pilar Nusa Mandiri, vol. 13, no. 2, pp. 193-198, 2017. 